\title{
Gp100:209-217 Peptide
}

National Cancer Institute

\section{Source}

National Cancer Institute. gp100:209-217 Peptide. NCI Thesaurus. Code C2766.

A synthetic peptide vaccine consisting of the amino acids 209 through 217 of the glycoprotein 100 (gp100) melanoma antigen. Vaccination with gp100_209-217 may stimulate the host immune system to mount a cytotoxic $T$ lymphocyte $(C T L)$ response against tumor cells positive for gp100, resulting in decreased tumor growth. (NCI04) 